\title{
AUTOMATED TASK MANAGEMENT SYSTEM USING ANALYTICAL HIERARCHY PROCESS
}

\author{
Sonya Meitarice ${ }^{1}$, Mumtaz Begum Peer Mustafa ${ }^{2}$, Dedek Okta Andi ${ }^{3}$ \\ ${ }^{1,2}$ Department of Software Engineering, Faculty of Computer Science and Information Technology \\ University of Malaya, 50603 Kuala Lumpur, Malaysia \\ ${ }^{3}$ Department of Psychology of Education, Faculty of Psychology \\ State Islamic University of Sultan Syarif Kasim, Riau \\ sonya.meitarice@gmail.com,mumtaz@um.edu.my,21950215495@students.uin-suska.ac.id
}

\begin{abstract}
In today's competitive environment, students have to manage a great variety of tasks, and sometimes, due to poor time management, they fall behind in completing the tasks well and on time. Thus, this research presents the research and development of an automated task management system using Analytical Hierarchy Process (AHP) measurement for task monitoring and provides alerts for university students, which can continuously monitor the student's task performance. To achieve the objective of this research, the following methodology was adopted. First, the research identifies suitable measures of poor time management, best time management practices for university students, and suitable solution for developing the proposed system. A preliminary investigation was carried out to identify problem faced by students with their task management and the impact on their academic performance. The respondents of this preliminary investigation are undergraduate and postgraduate students from the Faculty of Computer Science and Information Technology at the University of Malaya that have responded to a survey questionnaire. Based on the outcome of the preliminary investigation, it is clear that students prefer a computer application to constantly monitor tasks over the internet will ease the tasks of users.
\end{abstract}

Keywords: Task Management System, Personalization, Monitoring, Alert, Analytical Hierarchy Process 


\section{INTRODUCTION}

Having an effective task management, the ability in setting goals and priorities, and monitoring the use of time, can increase the productivity and reduces the stress, resulting in work efficiency, and academic success. From this expanded perspective, researchers can see that the real value of task management is to improve lives in all its dimensions. According to [1], one of the benefits of the Task Management System (TMS) for students, is that they can accomplish more academically, and therefore can achieve higher grades. Reference [2] state that the stress level among the students reduces when they manage their tasks well.

There are a few possible causes of student poor task management. First of all, students may not have a clear purpose in their study. According to, having a clear purpose in studies is positively correlated with the perceived effectiveness and morale of the students. Secondly, students can be easily distracted and interrupted, and these interruptions can rob a student's need, and a clear mind to achieve his/ her goals. Moreover, interruptions can break the student's focus [3]. The third cause is that the students cannot pay more attention to making a "to-do" list and studying without considering the exam dates. The fourth and final cause is that students are not being able to prioritize their tasks because they are not very sure as to which task is more important than others. Prioritizing tasks is a critical skill for student's success [4].

However, the current systems do not help the students in managing their academic tasks efficiently, especially in handling deadlines [5]. Most of the existing systems only offer basic features such as view and organize courses, work and learn together in forums, view grades, do an online quiz, and taking an online examination.

This study aims to identify the issues toward the development of task management systems by examining the symptoms and measures of poor task management and the best task management practices for university students. A survey was carried out among the university students to find the problems in task management.

This research contributes toward the body of knowledge on the need for an effective TMS and its relation to academic performance. The outcome of this research is an automated task management system incorporating software agents that can help the students to improve their academic performance. The issues of the existing TMS with poor monitoring and autonomy capability will be solved by the proposed system. The proposed system will also incorporate calendar display to improve the ease of use.

There have been several literatures that show the positive implication of good task management on the student's academic performance. Reference [6] state that, there is a significant relationship between the efficient use and management of task with the academic life satisfaction. A successful student with a good academic performance is a good task manager. Reference [3] found that most of the unsuccessful students study only before exams and that explains their low grades.

It is clear that the main educational goal of students, teachers or institutions will be the academic performance. Academic performance is commonly determined from examinations and the continuous assessment of students. However, there is no general agreement on what constitute good academic performance and the aspect in studies that are more critical in achieving it. Student's ability in managing tasks successfully and productively has a significant influence on academic performance. When a student better manages their tasks, their grades improve, and their stress level decreases [1].

Existing research also show that there was a significant relationship between procrastination and good academic performance. Students who tend to delay their college duties will have a negative academic achievement. Reference [7] confirmed that selfdiscipline is a must for students to plan and manage their task. According to [8], students that are lacking in regular or daily goals setting, perform badly in their academic activities. Reference [8] also found that students normally do not arrange or perform their tasks according to the order of importance and urgency.

To improve their academic performance, students are recommended to spend their time wisely judiciously [8]. It was found that academic performance improves with good task management skills such as prioritization. Prioritization of tasks can reduce stress and make studying more enjoyable. Academic stress occurs when students re pressured due to exams, rushing through their homework and not getting adequate sleep due to disorganizations 
and being worried too much. There was a significant relationship between task prioritization and academic achievements.

Reference [9] states that the ability to set priorities is one of the most important elements in task management. Similarly, [8] stated that there is a significant relationship between task prioritization and academic performance. However, students do not have the ability to plan their task and not be able to arrange their goals, according to the order of importance and urgency, which results in poor academic performance. However, some of the existing TMS such as Google task, Any.Do, Todolist, Wunderlist and Asana, offer very limited assistance to the students in prioritizing. These TMSs do not have the autonomy capability to set priority in each task automatically, where users are still creating to-do list item manually. On top of that, these systems are not being able to monitor the impending tasks, and offer very little useful tools (for example, there no calendar display which can help students to see and manage their task easily).

\section{METHODS}

Several researchers found that there was a significant relationship between procrastination and academic performance [7]. The students who always delay their college duties will produce poor academic performances. In order to improve their performance, they need to reduce the procrastination, and this can be achieved with self-discipline and proper planning of their time.

Reference [8] state that the students that do not regularly set their daily goals perform badly with their academic activities. This research also found that the students did not arrange or perform their goals, according to the order of importance and urgency. On top that, the research also indicates that there was a significant relationship between prioritization and academic performances.

Several researchers have identified measurement for poor task management [10]. One way to measure poor task management is the ability to meet the deadline [11]. When a deadline approaches, students with poor task management or passive procrastinator become pressured and have a pessimistic outlook, especially in their ability to achieve satisfactory results [12]. Reference [10] also found that students with poor task management prefer to work under pressure, and they make deliberate decisions to procrastinate. Individuals who always make the decision to postpone what is necessary to reach a goal, has a high intentional decision to procrastinate is also considered to have a poor task management habit. Reference [13] identified several symptoms of poor task management, such as, not having a clear purpose, and getting distracted and interrupted easily. Reference [1] stated that the inability to prioritize and monitor goals and tasks is a symptom of poor task management.

The majority of time management experts recommend task prioritization as an effective task management practices to reduce missing and delaying deadlines. Prioritization means that the student divides their task into most important and lease important using relevant. Table 1 shows the summary of some good task management practices.

Researchers generally agree that the existing Task Management Systems (TMS), need to be improved [8][9]. The existing TMSs do not have the capability for prioritization, causing these systems to be less effective in task management [9].

Table 1. Best task management practice

\begin{tabular}{cl}
\hline Authors & \multicolumn{1}{c}{ Best Time Management Practices } \\
\hline$[13]$ & $\begin{array}{l}\text { 1. Having a clear purpose, } \\
\text { 2. Planning and prioritizing, }\end{array}$ \\
& $\begin{array}{l}\text { 3. Avoiding interruptions and } \\
\text { distractions, }\end{array}$ \\
& $\begin{array}{l}\text { 4. Being organized. } \\
\text { 1. Choosing goals and sub-goals, }\end{array}$ \\
& $\begin{array}{l}\text { 2. Prioritizing the goals, } \\
\text { 3. Generating tasks and subtasks from } \\
\text { the goals, prioritizing the tasks, }\end{array}$ \\
& $\begin{array}{l}\text { 4. } \text { Listing the tasks on a "to-do" list, } \\
\text { 5. Scheduling the tasks, and then } \\
\text { carrying out the tasks. }\end{array}$ \\
& $\begin{array}{l}\text { Testing graduate students on a time- } \\
\text { management computer game. }\end{array}$ \\
& $\begin{array}{l}\text { Students attend time management } \\
\text { practice course for several weeks. }\end{array}$ \\
\hline 118$]$ &
\end{tabular}

\subsection{AHP (Analytical Hierarchy Process)}

Analytic hierarchy Process is one of the well-known tasks prioritization techniques developed by Saaty in 1977, 1980, and 1986 [14]. The working principle of the AHP is the simplification of a complex problem that is not structured, strategic and dynamic into its parts, and arrange in a hierarchy. The level of importance of each variable is given as a numerical value in relative terms to other 
variables. From these considerations, this technique can synthesize a variable that has a high priority.

Reference [15] state that the AHP is the most capable prioritization technique. Similarly, [16] found that the pairwise comparison in AHP is more precise, quicker and useful than the conventional numerical assignment. One of the advantages of AHP is that it measures a task as more than or less than important to a benchmark task numerically, and the one with the highest value is given the top priority. The steps of AHP calculation are as follows:

1. Input data of task

2. Input data of criteria.

3. Calculation of matrix pairwise comparisons among criteria, and an alternative (task).

4. Calculation of local priority value (criteria) and global (alternative value of the criteria).

5. List of task prioritization report.

The prioritization score from the AHP techniques will be used for monitoring tasks and providing suitable recommendations.

\subsection{Data Collection}

In this research, a survey questionnaire was administered to determine the perception of TMS among the students from the University of Malaya. The participants of the survey are the students from the Faculty of Computer Science and Information Technology. A total of 157 students has responded to the survey.

The questionnaire used for the survey has two parts. Part one probe how students manage their time, and part two, gauge the student's selection criteria for task prioritization. The questions for section one was taken mostly from the Time-Management Questionnaire [1]. A five-point Likert like scale was used in the survey ( $5=$ Excellent, 4=Very Good, 3=Good, $2=$ Poor, 1=Very Poor). Table 2 lists the questions applied in this research. Table 3 shows the demographic breakdown of the 157 respondents.

The data collected from the questionnaire are analyzed statistically, including the measure of mean, mode, standard deviation, minimum and maximum score. The analysis of variance (ANOVA) is also performed to determine any significant differences between the means of the male and female group, age groups and level of education.
Table 2. Time management questionnaire

\begin{tabular}{|c|c|c|}
\hline No & Questions & References \\
\hline 1 & \begin{tabular}{lr}
\multicolumn{3}{l}{ Do you often find yourself } \\
doing things which \\
interfere with & your \\
schoolwork & simply \\
because you hate & to say \\
"No" to people? &
\end{tabular} & [1] \\
\hline 2 & $\begin{array}{l}\text { Are you in charge of your } \\
\text { own time? }\end{array}$ & Self-Constructed \\
\hline 3 & $\begin{array}{l}\text { On an average class day } \\
\text { do you spend more time } \\
\text { on personal grooming } \\
\text { than doing schoolwork? }\end{array}$ & [1] \\
\hline 4 & $\begin{array}{l}\text { Do you believe that there } \\
\text { is room for improvement } \\
\text { in the way you manage } \\
\text { your time? }\end{array}$ & [1] \\
\hline 5 & $\begin{array}{l}\text { The night before a major } \\
\text { assignment is due, are you } \\
\text { usually still working on } \\
\text { it? }\end{array}$ & Self-Constructed \\
\hline 6 & $\begin{array}{l}\text { When you have several } \\
\text { things to do, do you think } \\
\text { it is best to do a little bit } \\
\text { of work on each one? }\end{array}$ & Self-Constructed \\
\hline 7 & $\begin{array}{l}\text { Do you have difficulties } \\
\text { in managing your study } \\
\text { time? }\end{array}$ & Self-Constructed \\
\hline 8 & $\begin{array}{l}\text { Do you write a set of } \\
\text { goals for yourself for each } \\
\text { day? }\end{array}$ & Self-Constructed \\
\hline 9 & $\begin{array}{l}\text { Are you constantly } \\
\text { delayed in submitting } \\
\text { your assignments? }\end{array}$ & Self-Constructed \\
\hline 10 & $\begin{array}{l}\text { Do you have the } \\
\text { necessary time } \\
\text { management skills? }\end{array}$ & Self-Constructed \\
\hline 11 & $\begin{array}{l}\text { Are you self-managing } \\
\text { your study? }\end{array}$ & Self-Constructed \\
\hline 12 & $\begin{array}{l}\text { Are you practicing good } \\
\text { time management? }\end{array}$ & Self-Constructed \\
\hline 13 & $\begin{array}{l}\text { Do you need help in } \\
\text { managing your study } \\
\text { time? }\end{array}$ & Self-Constructed \\
\hline 14 & $\begin{array}{l}\text { Do you prefer someone to } \\
\text { continuously monitor } \\
\text { your progress in } \\
\text { managing your study } \\
\text { time? }\end{array}$ & Self-Constructed \\
\hline 15 & $\begin{array}{l}\text { Do you like a computer } \\
\text { system that helps you to } \\
\text { identify poor time } \\
\text { management? }\end{array}$ & Self-Constructed \\
\hline 16 & $\begin{array}{l}\text { Do you want a system that } \\
\text { provides a personalized } \\
\text { solution to your poor time } \\
\text { management? }\end{array}$ & Self-Constructed \\
\hline
\end{tabular}


Table 3. The demographic of participants

\begin{tabular}{lcc}
\hline & \multicolumn{2}{c}{ Gender } \\
\hline & Male & Female \\
\hline Undergraduates & 57 & 66 \\
Post-graduates & 16 & 18 \\
\hline
\end{tabular}

Table 4 shows the mean score and standard deviation for each question of the Descriptive Statistic from the 157 participants' responses of the questionnaire. From Table 4, the highest mean score is for the question "Do you believe that there is room for improvement in the way you manage your time?" It is found that the majority of the respondents do believe that they can improve time management $(\mu=4.12)$. On the other hand, the question "Are you constantly delayed in submitting your assignments?" has the lowest mean score. It is found that the majority of students thinks that they are not procrastinating in completing their tasks. Though the majority of students is not constantly delaying in submitting their assignments $(\mu=2.15)$, they admitted that they are working on their assignment the night before the due date $(\mu=3.68)$, and the lastminute work can reduce the quality of work. The respondents are reluctant to have another person to oversee their activity $(\mu=2.55)$. They are more comfortable with a system to assist them in managing their academic task $(\mu=3.38)$.

Table 4. Mean and standard deviation of questionnaire

\begin{tabular}{|c|c|c|}
\hline Question & Mean & $\begin{array}{c}\text { Standard } \\
\text { Deviation }\end{array}$ \\
\hline $\begin{array}{l}\text { Do you often find yourself } \\
\text { doing things which interfere } \\
\text { with your schoolwork } \\
\text { simply because you hate to } \\
\text { say "No" to people? }\end{array}$ & 3.40 & 1.18 \\
\hline $\begin{array}{l}\text { Are you in charge of your } \\
\text { own time? }\end{array}$ & 3.85 & 0.88 \\
\hline $\begin{array}{l}\text { On an average class day do } \\
\text { you spend more time on } \\
\text { personal grooming than } \\
\text { doing schoolwork? }\end{array}$ & 2.42 & 1.11 \\
\hline $\begin{array}{l}\text { Do you believe that there is } \\
\text { room for improvement in } \\
\text { the way you manage your } \\
\text { time? }\end{array}$ & 4.12 & 1.01 \\
\hline $\begin{array}{l}\text { The night before a major } \\
\text { assignment is due, are you } \\
\text { usually still working on it? }\end{array}$ & 3.62 & 1.12 \\
\hline $\begin{array}{l}\text { When you have several } \\
\text { things to do, do you think it } \\
\text { is best to do a little bit of } \\
\text { work on each one? }\end{array}$ & 2.85 & 1.02 \\
\hline Do you have difficulties in & 3.00 & 1.04 \\
\hline
\end{tabular}

\begin{tabular}{lll}
\hline $\begin{array}{l}\text { managing your study time? } \\
\text { Do you write a set of goals } \\
\text { for yourself for each day }\end{array}$ & 2.82 & 1.11 \\
$\begin{array}{l}\text { Are you constantly delayed } \\
\text { in submitting your } \\
\text { assignments? }\end{array}$ & 2.13 & 1.00 \\
$\begin{array}{l}\text { Do you have the necessary } \\
\text { time management skills? }\end{array}$ & 3.43 & 0.81 \\
$\begin{array}{l}\text { Are you self-managing your } \\
\text { study? }\end{array}$ & 3.78 & 0.94 \\
$\begin{array}{l}\text { Are you practicing good } \\
\text { time management? }\end{array}$ & 3.20 & 1.01 \\
$\begin{array}{l}\text { Do you need help in } \\
\text { managing your study time? }\end{array}$ & 2.83 & 1.18 \\
$\begin{array}{l}\text { Do you prefer someone to } \\
\text { continuously monitor your } \\
\text { progress in managing your } \\
\text { study time? }\end{array}$ & 2.55 & 1.21 \\
$\begin{array}{l}\text { Do you like a computer } \\
\text { system that helps you to } \\
\text { identify poor time } \\
\text { management? }\end{array}$ & & \\
$\begin{array}{l}\text { Do you want a system that } \\
\text { provides personalized } \\
\text { solution to your poor time } \\
\text { management? }\end{array}$ & 3.38 & 1.26 \\
\hline
\end{tabular}

Table 5 compares the descriptive statistics of the score between the male and female students. The mean score for male and female respondents are 3.11 and 3.26 respectively. The standard deviation of the male and female respondents is 1.10 and 1.01 respectively.

Table 5. Comparison of descriptive statistic between

\begin{tabular}{lcc}
\multicolumn{3}{c}{ female and male students } \\
\hline $\begin{array}{c}\text { Descriptive } \\
\quad \text { Statistic }\end{array}$ & Male & Female \\
\hline Mean & 3.11 & 3.26 \\
Median & 3.16 & 3.34 \\
Mode & 3.00 & 3.00 \\
Std. Deviation & 1.10 & 1.01 \\
Skewness & -0.13 & -0.13 \\
Std. Error of & & 0.49 \\
Skewness & 0.38 & \\
Kurtosis & 0.06 & -0.38 \\
Std. Error of & & 0.95 \\
Kurtosis & 0.75 & \\
Minimum & 2.00 & 3.00 \\
Maximum & 5.00 & 5.00 \\
\hline
\end{tabular}

To determine any significant differences in the variance between male and female respondents, Analysis of Variance (ANOVA) was performed. Table 6 shows the results of the ANOVA, where it is clear that there are no significant differences in the responses between male and female respondents at $\mathrm{p}<0.05$. 
Table 6. Analysis of variance

\begin{tabular}{|c|c|c|c|c|c|}
\hline \multicolumn{6}{|c|}{ ANOVA } \\
\hline & $\begin{array}{c}\text { Sum } \\
\text { of } \\
\text { Square } \\
\text { s }\end{array}$ & df & $\begin{array}{c}\text { Mean } \\
\text { Squar } \\
\text { e }\end{array}$ & $\mathrm{F}$ & Sig \\
\hline $\begin{array}{l}\text { Between } \\
\text { Groups }\end{array}$ & 4.200 & 1 & 4.200 & $\begin{array}{r}2.9 \\
28\end{array}$ & $\begin{array}{r}.08 \\
7\end{array}$ \\
\hline $\begin{array}{l}\text { Within } \\
\text { Groups } \\
\text { Total }\end{array}$ & $\begin{array}{r}1374.4 \\
62 \\
1378.6 \\
63 \\
\end{array}$ & $\begin{array}{r}95 \\
8 \\
95 \\
9 \\
\end{array}$ & 1.435 & & \\
\hline
\end{tabular}

\subsection{Data Analysis and Survey}

Based on the data analysis of the survey, the majority of the respondents believe that they can improve the way they manage their time and tasks. Although most of the students do not delay in submitting their assignments before the due date, they agree that an automated system can help them in managing tasks.

The mean score of the responses between the male and female respondents are not significantly different at $\mathrm{p}<0.05$. It indicates that both the male and female student have the same necessity for a system to help them in managing tasks.

From the finding of the survey questionnaire, the majority of the students do believe that there is room for improvement for better task management. They also agree that an automated system can help them to better manage their task. The analysis of variance shows that there is no significant difference in the responses between male and female respondents.

\section{RESULTS AND DICUSSION}

\subsection{Scope of System}

The proposed system, which is called Spectrum Recommender (SR), is designed to help the students in monitoring the impending tasks and prioritize tasks based on certain criteria from the 57 participants responding such as mark percentage, number of chapter, and due date. Moreover, the system also provides regular notifications to the students for any new task published. The proposed system will also provide calendar display so that students can easily view and plan their tasks. The functional requirement of SR is analyzed by Object oriented Analysis and developed using PHP programming language.

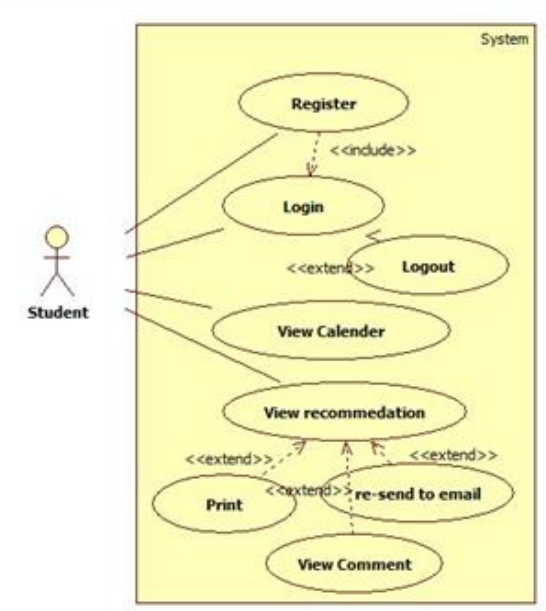

Figure 1. Spectrum recommender use case diagram

\subsection{Priority Measurement Using Analytical Hierarchy Process Technique}

The first step in calculating the AHP is comparing the data between the criteria in a pairwise matrix by using the intensity importance scale of the AHP. This process is performed to determine the comparative values of the consistency ratio (Consistence Ratio or $\mathrm{CR}$ ), where the consistency requirements must be smaller than $10 \%$ or $\mathrm{CR}<0.1$.

Before building the pairwise matrix among the criteria, the determined intensity of importance of each criterion needs to be established. The objective of this is to avoid the CR> 0.1 or inconsistent relationship among the criteria. The intensity of the importance values was based on data collected from the survey, where each criterion has a range of values from 1 to 9 as recommended by [19]. Table 6 shows the Pairwise Comparison Scale as proposed in [19].

Table 6. Pairwise comparison scale [19]

\begin{tabular}{|c|c|c|}
\hline $\begin{array}{l}\text { Intensity } \\
\text { of } \\
\text { Importance }\end{array}$ & Definition & Explanation \\
\hline 1 & $\begin{array}{l}\text { Equal } \\
\text { importance }\end{array}$ & $\begin{array}{l}\text { The two activities } \\
\text { contribute equally } \\
\text { toward achieving the } \\
\text { objective }\end{array}$ \\
\hline 3 & $\begin{array}{l}\text { Moderate } \\
\text { importance }\end{array}$ & $\begin{array}{l}\text { One activity is slightly } \\
\text { in favor over another }\end{array}$ \\
\hline 5 & $\begin{array}{l}\text { Strong } \\
\text { importance }\end{array}$ & $\begin{array}{l}\text { One activity is strongly } \\
\text { favored over another }\end{array}$ \\
\hline 7 & $\begin{array}{l}\text { Very strong } \\
\text { importance }\end{array}$ & $\begin{array}{l}\text { The activity is favored } \\
\text { very strongly over } \\
\text { another, signaling its } \\
\text { dominance }\end{array}$ \\
\hline
\end{tabular}


9 Extreme
importance

$2,4,6,8$

The survey results from the 60 respondents are used to obtain the intensity of importance as follows:

- Due date is more important than Chapters: intensity of importance $=3$

- Due date is strongly important than Mark: intensity of importance $=5$

- Chapter is more important than Mark: intensity of importance $=3$

After the intensity of the criteria was established, the next step is to prepare the comparison matrix between the criteria as shown in Table 7.

Table 7. The pairwise comparison matrix for each criterion

\begin{tabular}{llll}
\hline Criteria & Due Date & Chapter & Mark \\
\hline Due Date & 1 & 3 & 5 \\
Chapter & 0.33 & 1 & 3 \\
Mark & 0.2 & 0.33 & 1 \\
\hline
\end{tabular}

Before calculating the priority vector, the comparative value of each column is totaled up as shown in Table. 8.

Table 8. The sum of pairwise comparison matrix

\begin{tabular}{llll}
\hline \multicolumn{1}{c}{ Criteria } & Due Date & Chapter & Mark \\
\hline Due Date & 1 & 3 & 5 \\
Chapter & 0.33 & 1 & 3 \\
Mark & 0.2 & 0.33 & 1 \\
Total & 1.53 & 4.33 & 9 \\
\hline
\end{tabular}

Priority vector is then calculated by dividing the total of the columns with the numbers of criteria as follows,
Duedate $=\frac{\left(\frac{1}{1.53}\right)+\left(\frac{3}{4.33}\right)+\left(\frac{5}{9}\right)}{3}=0.63$

Chapter $=\frac{\left(\frac{0.33}{1.53}\right)+\left(\frac{1}{4.33}\right)+\left(\frac{3}{9}\right)}{3}=0.26$

Mark $=\frac{\left(\frac{0.2}{1.53}\right)+\left(\frac{0.33}{4.33}\right)+\left(\frac{1}{9}\right)}{3}=0.11$

Having obtained the priority criteria, lambda maximum $(\lambda \max )$ or eigenvalue is calculated by adding up the multiplication result of the priority vector with the number of columns. The purpose of the lambda is to determine the consistency in the value of each criterion,

dmaks $=(0.63 * 1.53)+(0.26 * 4.33)+(0.11 * 9)$

$$
=3055
$$

Then calculating the Consistency Index (CI) using the formula (2.3), where $\mathrm{n}=3$ (because the number of criteria is 3 )

$$
\begin{aligned}
C I & =\frac{\lambda \operatorname{maks}-n}{n-1} \\
& =\frac{3.055-3}{3-1}=0.027
\end{aligned}
$$

RI value for $\mathrm{n}=3$ is 0.58 , so $\mathrm{CR}$ (Consistency Ratio) can be calculated:

$$
\begin{aligned}
C R & =\frac{C I}{R I} \\
& =\frac{0.027}{0.58}=0.04(<10 \% \text { is consistency })
\end{aligned}
$$

After obtaining the weight values consistent priority for each criterion, the next step is to apply the weights to determine the priorities for a given task. Table 9 shows the sample case of four tasks and Table 10 to Table 12 show the calculation of the tasks given in Table 9.

Table 9. Sample case

\begin{tabular}{lllll}
\hline & Task 1 & Task 2 & Task 3 & Task 4 \\
\hline Chapter & 3 & 5 & 2 & 7 \\
Mark & $10 \%$ & $25 \%$ & $10 \%$ & $30 \%$ \\
$\begin{array}{l}\text { Due } \\
\text { Date }\end{array}$ & 5 Days & 7 Days & 2 Days & 3 Days \\
\hline
\end{tabular}


Table 10. Calculation of the priority vector for each task for the due-date criterion

\begin{tabular}{lcccl}
\hline Due date & Task 1 & Task 2 & Task 3 & Task 4 \\
\hline Task 1 & 1.00 & 1.40 & 0.80 & 1.40 \\
Task 2 & 0.71 & 1.00 & 0.57 & 1.00 \\
Task 3 & 1.25 & 1.75 & 1.00 & 1.75 \\
Task 4 & 0.71 & 1.00 & 0.57 & 1.00 \\
Priority & 0.27 & 0.19 & 0.34 & 0.19 \\
Vector & & & & \\
\hline
\end{tabular}

Table 11. Calculation of the priority vector for each task for the chapter criterion

\begin{tabular}{llccl}
\hline \multirow{2}{*}{ Chapter } & Task 1 & Task & Task & \multirow{2}{*}{ Task 4 } \\
& & 2 & 3 & \\
\hline Task 1 & 1.00 & 0.60 & 1.50 & 1.00 \\
Task 2 & 1.67 & 1.00 & 2.50 & 1.67 \\
Task 3 & 0.67 & 0.40 & 1.00 & 0.67 \\
Task 4 & 1.00 & 0.60 & 1.50 & 1.00 \\
Priority & 0.23 & 0.38 & 0.15 & 0.23 \\
Vector & & & & \\
\hline
\end{tabular}

Table 12. Calculation of the priority vector for each task for the mark criterion

\begin{tabular}{ccccc}
\multicolumn{5}{c}{ Task for the mark criterion } \\
\hline Mark & Task 1 & Task 2 & Task 3 & Task 4 \\
\hline Task 1 & 1.00 & 0.40 & 1.00 & 0.33 \\
Task 2 & 2.50 & 1.00 & 2.50 & 0.83 \\
Task 3 & 1.00 & 0.40 & 1.00 & 0.33 \\
Task 4 & 3.00 & 1.20 & 3.00 & 1.00 \\
Priority & 0.13 & 0.33 & 0.13 & 0.40 \\
Vector & & & & \\
\hline
\end{tabular}

Having obtained the all the weights for each criteria and weighted values for each of the tasks (task 1, task 2, task 3, and task 4), the last step is to calculate the average value for each of the tasks, known as the overall composite weight, as indicated in table 5.8.

Composite Overall weight is calculated as follows:

- Weight column taken from the Priority vector

- All tasks (Task 1, Task 2, Task 3, and Task 4) are taken from the third column matrix, which are Priority Vector Due date, Mark and Chapter.

- Weight Composite line derived from the number of cells multiplied with the weight.
Table 13. Overall composite weight

\begin{tabular}{lclll}
\hline $\begin{array}{c}\text { Overall } \\
\text { Composite } \\
\text { Weight }\end{array}$ & $\begin{array}{c}\text { Due } \\
\text { date }\end{array}$ & Chapter & Mark & $\begin{array}{c}\text { Average } \\
\text { Value }\end{array}$ \\
\hline Task 1 & 0.27 & 0.23 & 0.13 & 0.25 \\
Task 2 & 0.19 & 0.38 & 0.33 & 0.26 \\
Task 3 & 0.34 & 0.15 & 0.13 & 0.27 \\
Task 4 & 0.19 & 0.23 & 0.40 & 0.23 \\
Priority & 0.63 & 0.26 & 0.11 & \\
Vector & & & & \\
Criteria & & & & \\
\hline
\end{tabular}

Based on Table 13, it can be concluded that the highest score is for Task $\mathbf{3}$, which is 0.27 , followed by Task 2 of 0.26 , Task 1 of 0.25 and, finally Task 4 , with a score of 0.23 .

\subsection{System Process Design}

After the calculation of priority value, SR system will arrange the tasks according to the highest priority to the lowest priority and notify the student through email. The SR System will also count the days for completion and alert the students based on color presentation, Yellow (completion in more than 10 days), orange (completion 10 to 5 days), and red (less than 5 days).

\subsection{System Implementation}

SR System will monitor the tasks, such as the one still in progress, and the one that is completed. The system also shows the status of the task. The system counts the days that the tasks need to be completed and provide specific colors for representing urgency. Yellow (completion in more than 10 days), orange (completion 10 to 5 days), and red (less than 5 days). SR system will arrange the tasks, from the highest priority to the lowest priority using AHP (analytical Hierarchy Process) as shown in Figure 2. The system also alerts the student through email for any new tasks published by the lecturer as shown in Figure 3. 


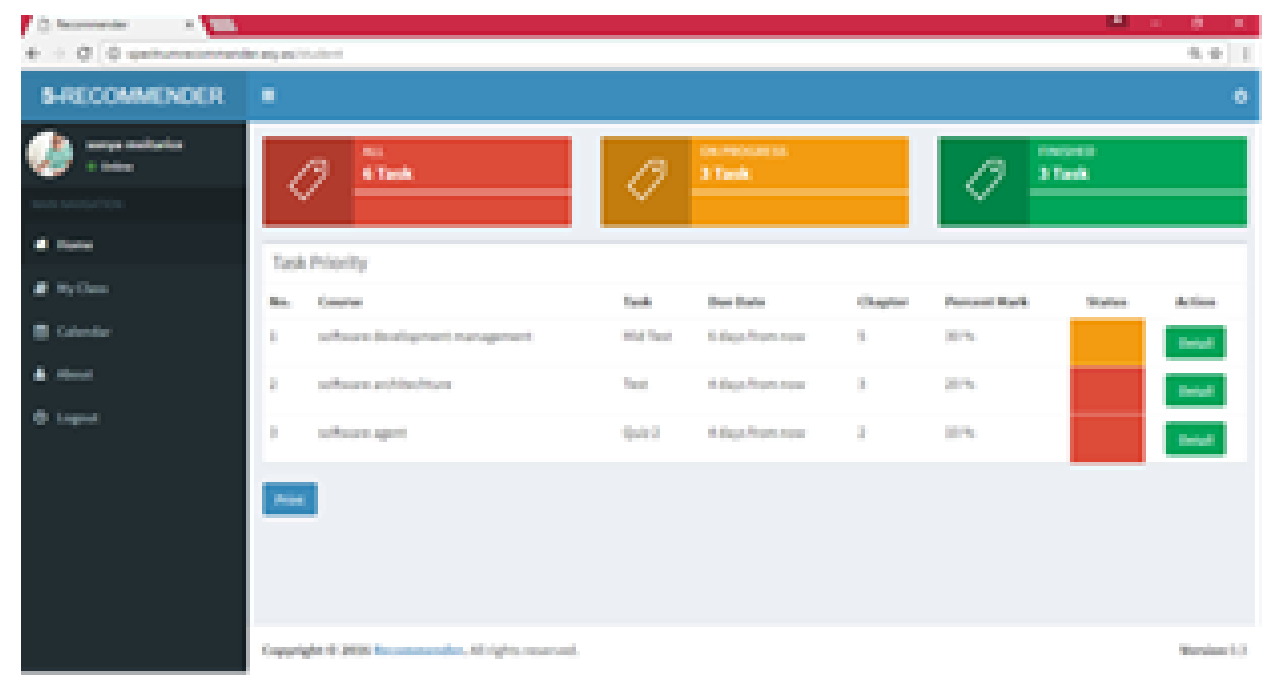

Figure 2. Task monitoring and recommendation

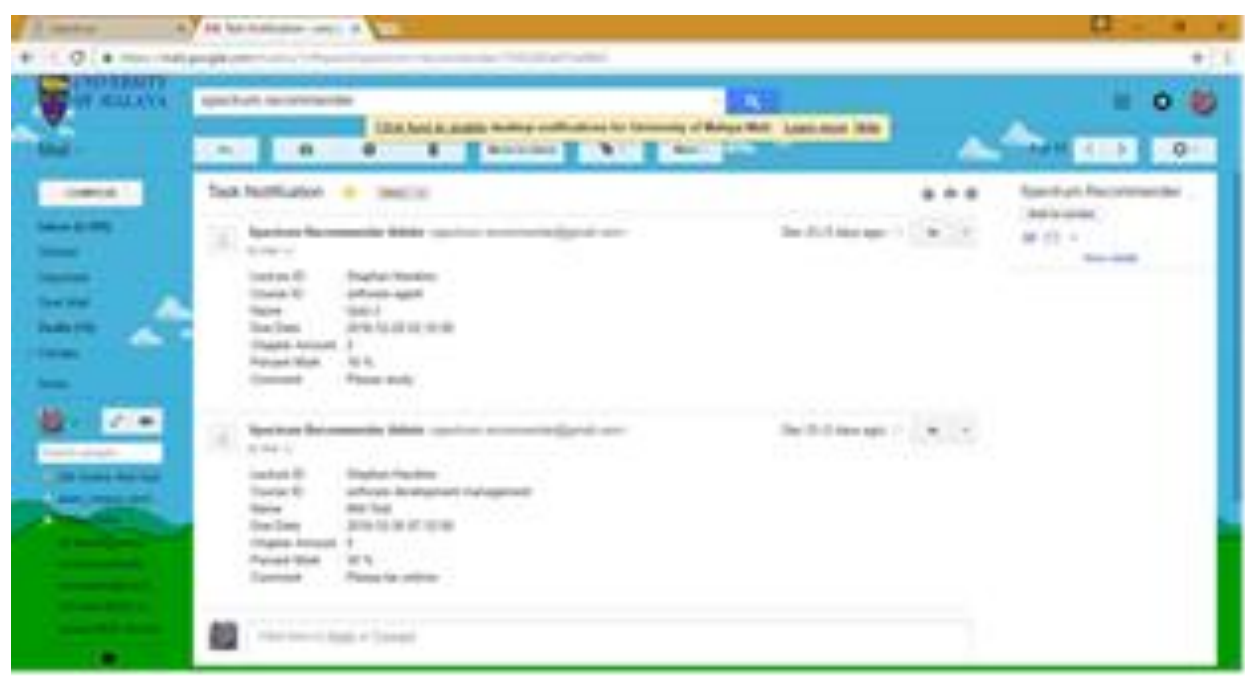

Figure 3. Task alert

Figure 4 shows the evaluation result on the Spectrum Recommender System. From the evaluation, $10.5 \%$ of respondents chose for undecided/ no opinion on how the system performs its role, which may be due to the inability of the respondents to understand the role of the system. On the other hand, $40.4 \%$ respondents agree, and $49.1 \%$ respondents strongly agree that the system performs its role. This means that about $90 \%$ of the respondents agree that the SR system help them in avoiding submitting assignments. 


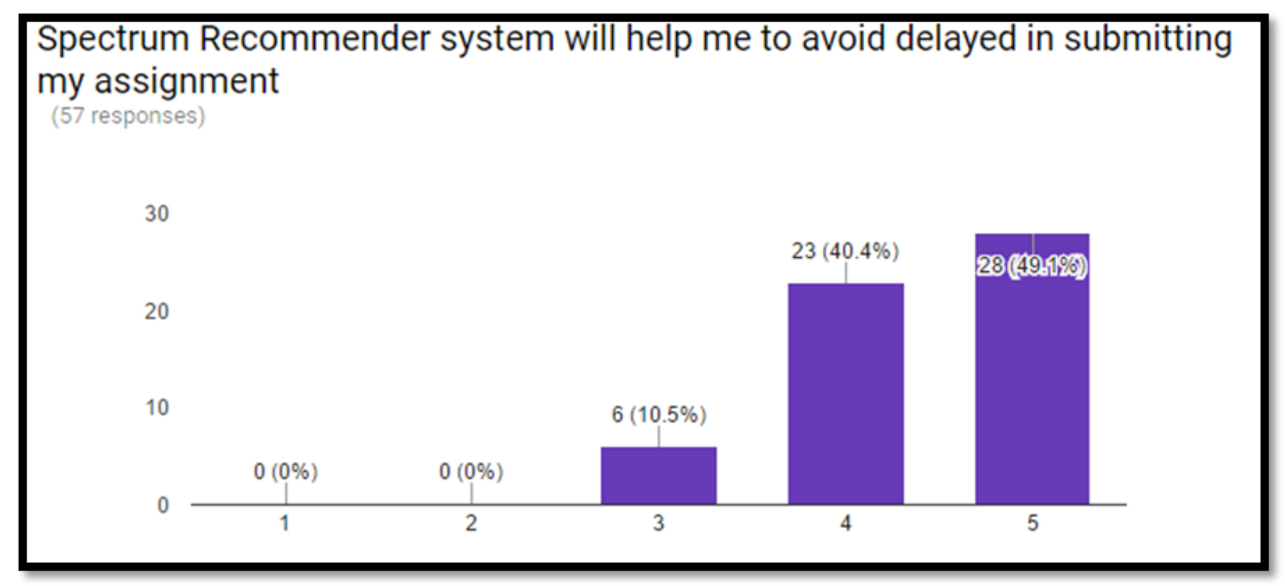

Figure 4. System performance evaluation result

Then, Figure 5 shows the evaluation result on the System role of Managing Tasks. From the evaluation, $14 \%$ of respondents select undecided/ no opinion on how the system does the role. $31.6 \%$ of respondents agree and $54.4 \%$ respondents strongly agree that the system performs its role in managing the task. In summary, about $86 \%$ of the respondents agree that the SR help them to manage their tasks. 


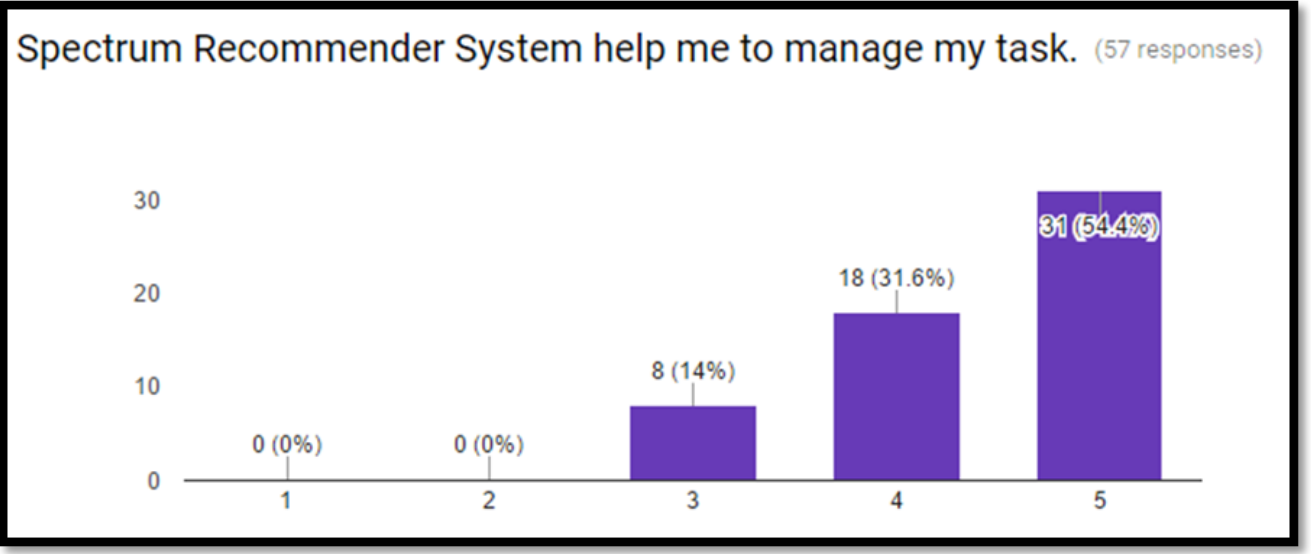

Figure 5. System performance evaluation result

The evaluation for the system performance and acceptance scores given by the male and female respondents on the SR was not different statistically despites the slight difference in the mean score between male and female respondents. This indicates that both the male and female respondents agree that the SR achieved its intended performance and acceptance by the target users. However, when comparing the respondents' level of education, and age group, there was a significant difference in the responses between the younger (undergraduates and Master students) with older (Ph.D students) respondents. It suggests that older users are not very keen with an automated system to manage their tasks. On the contrary, the younger users are not very happy with the user interface as opposed to the older users, as they deemed the UI as not very friendly.

\section{CONCLUSION}

The main focus of this research is on the development of an automated system that can help the students in monitoring their task. From the previous research and survey, it is found that the students have difficulties in managing their tasks. The student generally cannot plan themselves and not be able to arrange their goal based on the order of importance or urgency, and this will have a negative impact on their academic performance. The root causes of this, is that students are not being able to prioritize in setting their goals, get interrupted easily and delays in doing their assignments.

Existing Task Management Systems (TMS) are not much help to the student in managing their tasks. These systems do not have the autonomy capability to set priority in each task automatically and are not being able to monitor the impending tasks. From the findings of the literature review, it was found that a task management system incorporated prioritizing ability, which offers suggestions of educational bibliographic, materials and tools can help learners to accomplish their goals.

\section{REFERENCES}

[1] B. K. Britton and A. Tesser, "Effects of time-management practices on college grades," in J. Educ. Psychol., Vol. 83, no. 3, pp. 405-410, DOI: 10.1037/0022-0663.83.3.405. 1991.

[2] R. Misra, "College students' academic stress and its relation to their anxiety, time management, and leisure satisfaction," Copyright (C) 2000 All Rights Reserved," no. January 2000, 2016.

[3] F. Z. Miqdadi, et al., "The relationship between time management and the academic performance of students from the petroleum institute in Abu Dhabi, the UAE," in ASEE 2014 Zo. I Conf., pp. 1-5, 2014.

[4] M. Torenbeek, E. Jansen, and C. Suhre, 'Predicting undergraduates' academic achievement: the role of the curriculum, time investment and self-regulated learning," in Stud. High. Educ., 2013.

[5] M. E. Bulger, et al., "Measuring learner engagement in computer-equipped college classrooms," in J. Educ. Multimed. Hypermedia, Vol. 17, no. 2, pp. 1-23, 2008.

[6] M. Daili, "The university student' time 
management skill in terms of their academic life satisfaction and academic achievement levels," in Educ. Res. Rev., vol. 9 (21), pp. 1090-1096, 2014.

[7] A. Argawal, "Self discipline for student-influences on time management," 2008. [Online] Available: http://www.ezinarticles.com

[8] A. F. Aduke, "Time management and students academic performance in higher institutions, Nigeria - A case study of Ekiti State," in Int. Res. Educ., Vol. 3, no. 2, p. 1, DOI: 10.5296/ire.v3i2.7126. 2015.

[9] Mercanlioglu., "The relationship of time management to academic performance of master level students," in Int. J. Bus. Manag. Stud., Vol. 2, no. 1, pp. 25-36, 2010.

[10] J. N. Choi, "Rethinking procrastination: positive effects of 'active' procrastination behavior on attitudes and performance," in J. Soc. Psychol., no. June 2005.

[11] S. V. Choi, J. N., and Moran, "Why not procrastinate? Development and validation of a new active procrastination scale," in J. Soc. Psychol., Vol. 149, pp. 195-211, 2009.

[12] J. R. Ferrari, "Procrastination as selfregulation failure of performance: Effects of cognitive load, selfawareness, and time limits on 'working best under pressure.," in Eur. J. Pers., 2001.

[13] H. Kearns and M. Gardiner, "Is it time well spent? The relationship between time management behaviours, perceived effectiveness and workrelated morale and distress in a university context," in High. Educ. Res. Dev., Vol. 26, no. 2, pp. 235-247, 2007.

DOI: 10.1080/07294360701310839.

[14] M. Bernasconi, C. Choirat, and R. Seri, "The analytic hierarchy process and the theory of measurement," Manage. Sci., Vol. 56, no. 4, pp. 699-711, 2010. DOI: 10.1287/mnsc.1090.1123.

[15] J. Karlsson, C. Wohlin, and B. Regnell, "An evaluation of methods for prioritizing software requirements," in Inf. Softw. Technol., Vol. 39, no. 1415, 1998, pp. 939-947, DOI: 10.1016/s0950-5849(97)00053-0.
[16] A. Khan, et al., "Comparison of requirement prioritization techniques to find best prioritization technique," in International Journal of Modern Education and Computer Science, Vol. 7, no. 11,2015 , pp. 53-59. DOI: https://doi.org/10.5815/ijmecs. 2015.11.06.

[17] M. K. Tulga, T. B. Sheridan, "Dynamic decisions and workload in multitask supervisory control," in IEEE Transactions on Systems, Man, and Cybernetics, Vol. 10, no. 5, pp. 217 232, 1980.

[18] B. L. Hall and D. E. Hursch, "An evaluation of the effects of a time management training program on work efficiency," in Journal of Organizational Behavior Management, Vol. 3, no. 4, pp. 73-96, 1982. DOI: 10.1300/J075v03n04_08

[19] T.L. Saaty, "What is the analytic hierarchy process?" in Mitra G., Greenberg H.J., Lootsma F.A., Rijkaert M.J., Zimmermann H.J. (eds) Mathematical Models for Decision Support. NATO ASI Series, 1988. (Series F: Computer and Systems Sciences), Vol. 48. Springer, Berlin, Heidelberg. $\quad$ DOI: https://doi.org/10.1007/978-3-64283555-1_5

\section{Copyright}

All unpublished manuscripts may be submitted elsewhere. The author is responsible for the permission of publication or recognition of images, tables and numbers in the submitted manuscript. The manuscript is not a plagiarized text and does not infringe the rights of other third parties. The author agrees that the decision to publish or not publish the manuscript in the journal submitted by the author, is entirely the right of journal manager. Prior to final acceptance of the manuscript, the authors are required to affirm in writing that the submitted manuscript is the copyright of author and assigns this copyright to the journal manager. 